\title{
PERTUMBUHAN, MORTALITAS, DAN KEBIASAAN MAKAN IKAN TAWES (Barbodes gonionotus) DI WADUK WONOGIRI
}

\author{
Kunto Purnomo") dan Endi Setiadi Kartamihardja“")
}

\begin{abstract}
ABSTRAK
Total produksi perikanan tangkap Waduk Wonogiri yang memiliki luas sekitar 6.480 ha antara tahun 1998 2000 berkisar antara 3.300,8-3.510 ton per tahun. Ikan tawes (Barbodes gonionotus) adalah salah satu dari lima jenis ikan ekonomis penting di waduk tersebut, produksinya pada tahun 2000 mencapai 1.390 ton atau sekitar $40 \%$ dari total produksi tangkapan ikan. Penelitian tentang pertumbuhan, mortalitas, dan makanan ikan tawes yang dilakukan di Waduk Wonogiri dari bulan Januari sampai Desember tahun 2000 bertujuan untuk mendapatkan informasi untuk pengelolaan ikan tersebut di Waduk Wonogiri. Estimasi parameter pertumbuhan dari von Bertalanffy dan mortalitas ikan tawes dihitung memakai paket program FISAT. Analisis isi perut ikan tawes dihitung dengan menggunakan indeks preponderan. Hasil penelitian menunjukkan bahwa kisaran panjang (total) ikan tawes di Waduk Wonogiri berkisar antara 11,0-39,0 cm dengan berat antara 20,0-1100,0 gram. Pertumbuhan panjang-berat ikan tawes jantan maupun betina bersifat isometrik. Rasio antara ikan tawes jantan dan betina adalah 1:2. Nilai parameter pertumbuhan von Bertalanffy ikan tawes berdasarkan data kelamin gabungan (jantan dan betina) adalah sebagai berikut: $L_{\infty}=47,3 \mathrm{~cm}, k=0,42$ per tahun dan indeks performansi pertumbuhan sebesar 2,973. Laju mortalitas alami (M) adalah sebesar 0,89 per tahun dan mortalitas penangkapan (F) sebesar 0,17 per tahun sehingga mortalitas total $(Z)$ sebesar 1,06 per tahun (berkisar antara 0,93-1,19). Laju eksploitasi (E) stok ikan tawes diperkirakan sebesar 0,16. Makanan ikan tawes di Waduk Wonogiri ialah tumbuhan air/makrofita $(73,4-87,3 \%)$, detritus $(8,4-16,2 \%)$ dan fitoplankton (3,8-12,5\%), sehingga digolongkan ke dalam ikan herbivora. Walaupun tingkat eksploitasi ikan ini masih tergolong rendah namun pengelola perikanan harus tetap mendorong nelayan agar mempunyai rasa tanggung jawab yang besar terhadap kelestarian sumber daya ikan, khususnya ikan tawes.
\end{abstract}

ABSTRACT: Growth, mortality and feeding habits of Java barb (Barbodes gonionotus) in the Wonogiri Reservoir. By: Kunto Purnomo and Endi Setiadi Kartamihardja

The total fish catch of Wonogiri reservoir (6.480 ha) in 1998-2000 range from 3300.8 to 3510.0 ton per year. The Java barb (Barbodes gonionotus) being one of the five major commercially important species in the reservoir, constitutes about 1.390 ton or $40 \%$ of the total catch. Studi on the growth, mortality, and feeding habits of Java barb was conducted in Wonogiri reservoir from January to December 2000. The objective of the study is to provide information, relevant to the management of Java barb in the reservoir. The von Bertalanffy growth parameters and mortality rate were estimated from length frequency data using FISAT program. The growth performance index $\left(\Phi^{\prime}\right)$ was computed from the equation of Pauly \& Munro's (1984). Analysis of the stomach contents was carried out to evaluate their fe日ding preferences. Results show that the total length of individuals of java barb ranged from 11.0 to $39.0 \mathrm{~cm}$, and the weight from 20.0 to $1100.0 \mathrm{~g}$. The length-weight regression both for males $(b=2.938 \pm 0.084)$ and females $(b=3.008 \pm 0.041)$ indicated isometric growth. The overall sex ratio was $1: 2$ in favour of females. The von Bertalanffy growth parameters for the sexes combined were: $L_{\infty}=47.3 \mathrm{~cm}$ total length; $k=0.42$ year $^{-1}$; and the $\Phi^{\prime}$ (phi-prime) $\theta$ stimation was 2.973. Natural mortality rate, $M$, was 0.89 year $^{-1}$, fishing mortality $(F)$ was 0.17 yəar ${ }^{-1}$ and the total mortality rate (Z) was 1.06 year $^{-1}$ (range from 0.93-1.19) and the exploitation rate (E) was 0.16 . The diets of Java barb composed of macrophytes $(80.41 \pm 1.27 \%)$, detritus $(12.17 \pm 0.95 \%)$ and phytoplankton $(7.43 \pm 1.01 \%)$. It indicates that the Java barb is herbivorous species. Although the Java barb stock was exploited below the optimum level the fisheries manager should recommend the fisher to take greater responsibility for the sustainability and conservation of the fisheries resources.

KEYWORDS: growth, mortality, diets, Java barb, Wonogiri Reservoir

\section{PENDAHULUAN}

Waduk Wonogiri secara administratif termasuk Kabupaten Wonogiri, Propinsi Jawa Tengah. Perairan waduk yang luasnya sekitar 6.480 ha, kedalaman maksimum $28 \mathrm{~m}$ (rata-rata $8 \mathrm{~m}$ ) dan tergolong sangat subur (Purnomo, 2000; Purnomo et. al., 2003) tersebut terletak pada ketinggian 100-140 m d.p.I. (dari permukaan laut) dan posisi geografisnya antara $110^{\circ} 51^{\prime} 36^{\prime \prime}-110^{\circ} 58^{\prime} 12^{\prime \prime}$ BT dan 7 47'24"-8 01'12" LS.
Potensi produksi ikan ditaksir sekitar 5.520,5 ton per tahun (Purnomo, 2000). Penangkapan ikan merupakan kegiatan perikanan yang dominan di waduk tersebut, antara tahun 1998-2000 produksinya berkisar antara $3.300,8$ sampai $3.510,0$ ton per tahun. Berarti potensi sumber daya ikannya sudah dimanfaatkan sekitar $60-64 \%$, yaitu suatu tingkatan yang sudah memerlukan perhatian yang serius dari pihak pengelola perikanan setempat terhadap aspekaspek daya dukung dan kelestarian sumber daya.

\footnotetext{
.. Peneliti pada Loka Riset Pemacuan stok Ikan, Jatiluhur

*) Peneliti pada Pusat Riset Perikanan Tangkap, Jakarta
} 
Secara taksonomi ikan tawes (Barbodes gonionotus) termasuk ke dalam famili Cyprinidae. Sebelum Waduk Wonogiri dibendung, ikan tawes adalah ikan asli (indigenous species) Sungai Bengawan Solo tetapi setelah Waduk Wonogiri terbentuk ikan ini mampu beradaptasi dengan kondisi lingkungannya yang baru yaitu perairan yang menggenang (lentic) sehingga jenis ikan ini masih tetap ada sampai sekarang. Kontribusi hasil tangkapan ikan tawes pada tahun 2000 sekitar 1.390 ton atau $40 \%$ dari total hasil tangkapan. Produksi tangkapan tersebut adalah yang tertinggi dibanding jenis-jenis ikan lainnya yang juga sering tertangkap seperti ikan nila (Oreochromis niloticus), garingan/keting (Mystus nigriceps), bader (Barbodes balleroides), lukas (Labiobarbus festivus), palung (Hampala macrolepidota), patin (Pangasius sp.), dan sogo (Mystus nemurus).

Ikan tawes adalah salah satu jenis ikan ekonomis dan disukai oleh masyarakat setempat, di tingkat pengecer ikan ini dijual dengan harga antara $\mathrm{Rp}$. 6.000,--Rp. 7.000,- per kilogram. Daerah pemasarannya tidak saja di sekitar Kota Wonogiri tetapi sudah merambah hingga ke daerah Wonosari, Tulung Agung, Muntilan, Yogyakarta, dan Kudus. Diduga permintaan pasar yang cukup baik tersebut secara langsung atau tidak langsung telah menyebabkan intensitas penangkapan meningkat tajam. Akibatnya pada akhir-akhir ini hasil tangkapan ikan menurun, terutama ikan tawes. Menanggapi hal ini, Pemerintah Daerah Kabupaten Wonogiri telah melakukan upaya peningkatan stok (stock enhancement) yaitu dengan menebarkan sejumlah benih ikan tawes yang dilakukan sejak tahun 1981 . Upaya ini tidak pernah dimonitor dan dievaluasi keberhasilan/kegagalannya, perencanaan awalnya pun kurang mempertimbangkan hasil kajian secara ilmiah, terutama dari hasil-hasil penelitian yang pernah dilakukan di waduk tersebut. Fenomena semacam ini sebenarnya tidak hanya terjadi di Waduk Wonogiri, tetapi sudah menjadi ciri perikanan di negara yang sedang berkembang (Welcome, 1996; Welcomme \& Bartley, 1998; Cowx, 1999; Lorenzen et. al., 2001).

Bertolak dari permasalahan tersebut di atas dilakukan penelitian dengan tujuan untuk mendapatkan data dan informasi tentang aspek pertumbuhan, mortalitas, dan makanan ikan tawes. Hasil penelitian ini diharapkan bisa dimanfaatkan sebagai bahan masukan dalam penyusunan rencana pengelolaan sumber daya ikan, khususnya ikan tawes di Waduk Wonogiri.

\section{BAHAN DAN METODE}

Penelitian dilakukan di Waduk Wonogiri Propinsi Jawa Tengah, dari bulan Januari sampai Desember 2000. Data ukuran morfometri ikan, yaitu panjang total (diukur hingga skala terkecil yaitu $0,1 \mathrm{~cm}$ ) dan berat (ditimbang hingga ketelitian 5,0 gram) tiap individu ikan tawes diperoleh dengan cara memonitor hasil tangkapan nelayan yang dilakukan setiap bulan di Tempat Pendaratan Ikan (TPI) Desa Wuryantoro, Kecamatan Wuryantoro dan TPI Desa Kedungombo, Kecamatan Baturetno. Adapun dasar pertimbangan pemilihan kedua TPI tersebut ialah karena kedua TPI tersebut tergolong besar dan banyak nelayan yang mendaratkan hasil tangkapan di TPI. Dengan demikian bisa diasumsikan bahwa hasil tangkapan di kedua TPI tersebut bisa mencerminkan hasil tangkapan ikan di Waduk Wonogiri. Data hasil pengukuran panjang dan berat ikan tersebut dianalisis untuk mengetahui sifat pertumbuhan ikan, apakah isometrik $(b=3)$ atau alometrik $(b \neq 3)$, yaitu dihitung dari hubungan antara panjang dan berat ikan memakai rumus:

$$
W=a^{*} L^{b}
$$

di mana:

$$
\begin{array}{ll}
\mathrm{W} & =\text { berat ikan }(\mathrm{gram}) \\
\mathrm{L} & =\text { panjang total }(\mathrm{cm})
\end{array}
$$

$a$ dan $b=$ konstanta.

Nilai konstanta "b" yang diperoleh dari persamaan tersebut di atas selanjutnya diuji ketepatannya terhadap nilai $b=3$ menggunakan "uji $t$ ". Pendugaan parameter pertumbuhan dari Von Bertalanffy yaitu panjang total asimtotik ( $\left.L_{\infty}\right)$ dan koefisien pertumbuhan (k) dihitung memakai ELEFAN I (1987) seperti yang terdapat di dalam paket program komputer FISAT (Gayanillo et. al., 1995). Indeks performansi pertumbuhan ( $\Phi^{\prime}$, phi-prime) dihitung menggunakan persamaan Pauly \& Munro (1984) sebagai berikut:

$$
\Phi^{\prime}=\log _{10} k+2 \log _{10} L_{\infty}
$$

Laju mortalitas alami (M) diduga memakai model empiris dari Pauly (1980) sebagai berikut:

In $M=-0,0152-0,279^{*} \ln L_{\infty}+0,6543^{*} \ln k+0,4634^{*} \ln T$.

di mana:

$T=$ rataan suhu lingkungan perairan Waduk Wonogiri, yaitu $28^{\circ} \mathrm{C}$

Koefisien mortalitas total (Z) diperoleh dari kurva hasil tangkapan berdasarkan panjang (lengthconverted catch curve) (Pauly, 1983) yang penghitungannya dilakukan secara komputerisasi memakai paket program FiSAT (Gayanilo et. al., 1995). Koefisien mortalitas penangkapan ( $F)$ dihitung dari persamaan $F=Z-M$. Laju eksploitasi $(E)$ dihitung menggunakan persamaan $E=F / Z$ (Pauly, 1980).

Sampel ikan yang diperlukan untuk analisis preferensi makanan selain diperoleh dari hasil tangkapan nelayan, juga dari hasil percobaan penangkapan ikan memakai eksperimental gi'.'net berukuran mata jaring 25,$0 ; 37,5 ; 50,0 ; 75,0 ; 87,5$; 100,$0 ; 112,5$; dan 125 mm (stretch meshed). Sampel 
diamati gonadnya secara makroskopik untuk mengetahui jenis kelamin dan tingkat kematangan gonadnya, kemudian diawetkan dengan larutan formalin $10 \%$ untuk dianalisis lebih lanjut di laboraturium. Kebiasaan makan ikan tawes diketahui dengan cara menganalisis isi lambung dihitung memakai metode indeks preponderan (Natarajan \& Jhingran dalam Effendie, 1979), yaitu:

$$
\mathrm{I}_{i}=\left\{\left(\mathrm{V}_{i}^{*} \mathrm{O}_{i}\right) / \Sigma\left(\mathrm{V}_{i}^{*} \mathrm{O}_{i}\right)\right\}^{\star} 100 \%
$$

di mana:
$\mathrm{l}_{i} \quad=$ indeks prepoderan jenis makanan ke- $i$
$V_{i}=$ persentase volume pakan ke- $i$
$\mathrm{O}_{i}=$ persentase kejadian pakan ke- $i$

\section{HASIL DAN BAHASAN}

Hasil monitoring terhadap tangkapan nelayan di Waduk Wonogiri dari bulan Januari hingga Desember tahun 2000 diperoleh 2.152 ekor ikan tawes (Gambar 1), panjangnya berkisar antara $8,0-45,0 \mathrm{~cm}$ (rata-rata $28,3 \pm 0,1 \mathrm{~cm}$ ) dan beratnya antara 20,0-1.100,0 gram (rata-rata $384,6 \pm 6,0 \mathrm{~g}$ ). Hasil analisis hubungan antara panjang-berat ikan tawes menunjukkan bahwa pertumbuhan ikan tawes jantan mengikuti persamaan $W=0,016 L^{2,938}\left(S_{b}=0.084 ; N=268 ; R^{2}=0,946\right)$, betina mengikuti persamaan $\mathrm{W}=0,014 \quad \mathrm{~L}^{3,008} \quad\left(\mathrm{SE}_{b}=0,041\right.$; $\mathrm{N}=1884 ; R^{2}=0,917$ ) (Gambar 2) dan gabungan ikan jantan-betina mengikuti persamaan $W=0,012 \quad L^{3.039}$ $\left(\mathrm{SE}_{b}=0,034 ; \mathrm{N}=2.152 ; \mathrm{R}^{2}=0,936\right)$.

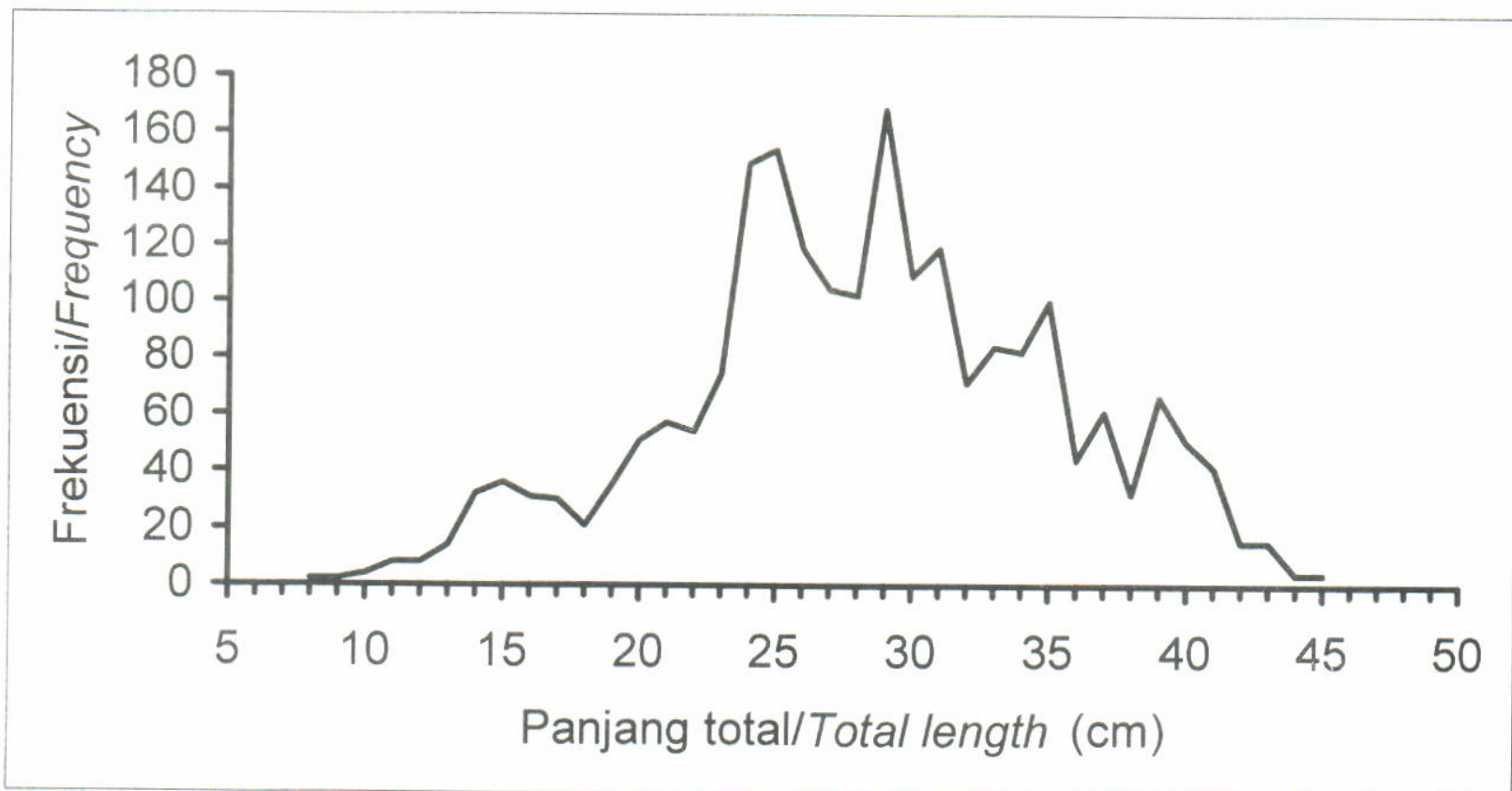

Gambar 1. Distribusi frekuensi panjang total ikan tawes (Barbodes gonionotus) di Waduk Wonogiri.

Figure 1. Total length frequency distribution of Java barb (Barbodes gonionotus) in the Wonogiri reservoir.
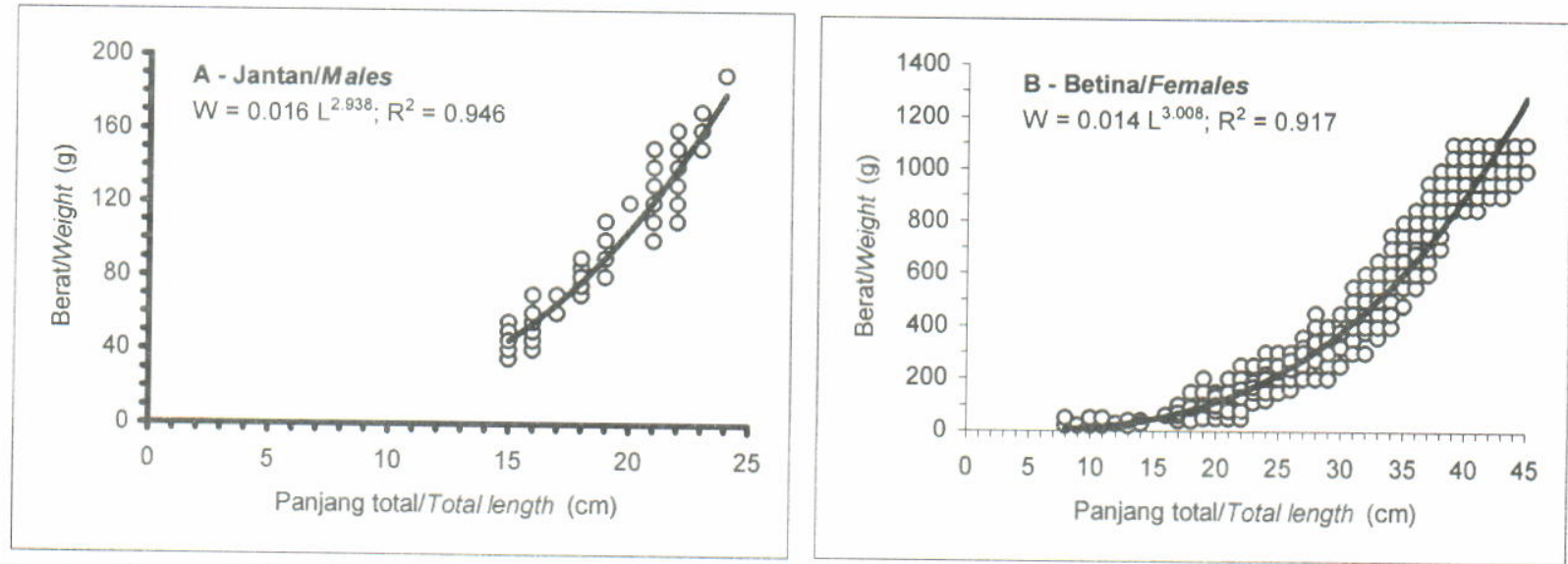

Gambar 2

Figure 2.

Hubungan panjang-berat ikan tawes (Barbodes gonionotus) jantan (a) dan betina (b). Length-weight relationship of males (a) and females (b) Java barb (Barbodes gonionotus). 
Berdasarkan nilai konstanta b pada ikan jantan maupun betina menunjukkan bahwa pertumbuhannya bersifat isometrik, artinya pertambahan panjang badan sebanding dengan beratnya. Apabila data ikan jantan dan betina digabungkan maka diperoleh nilai konstanta b (gabungan) sebesar $3,03 \pm 0,03$, artinya bahwa secara umum pertumbuhan ikan di waduk adalah bersifat isometrik. Sifat pertumbuhan ini tidak sama dengan yang diperoleh dari hasil penelitian di Waduk Kedungombo, yaitu $b=3,184$ (Katramihardja, 1995).

Menurut Dulčić et. al., (2003), nilai konstanta b dipengaruhi oleh tingkat perkembangan ontogenetik seperti perbedaan umur, tingkat kematangan gonad, dan jenis kelamin. Lebih lanjut Bagenal \& Tesch (1978) menambahkan bahwa nilai konstanta b juga dipengaruhi oleh letak geografis, kondisi lingkungan seperti musim, tingkat kepenuhan lambung, penyakit, dan parasit. Kemiripan kedua nilai konstanta b tersebut juga tercermin dari nilai indeks performansi pertumbuhan $\left(\Phi^{\prime}\right.$, phi-prime) ikan tawes di Waduk Wonogiri dan Kedungombo yaitu masing-masing sebesar 2,973 dan 2,977 (Tabel 1).

Berdasarkan hasil penelitian yang dilakukan oleh Purnomo (1997) di Waduk Jatiluhur, menunjukkan bahwa hubungan antara lingkar badan maksimum $\left(G_{m}\right.$, maximum girth, dalam $\left.\mathrm{cm}\right)$ dan panjang total $(L$, dalam $\mathrm{cm}$ ) ikan tawes mengikuti persamaan: $\mathrm{G}_{\mathrm{m}}=-$ $1,19+0,80 \mathrm{~L}$, dan hubungan antara lingkar badan maksimum dan ukuran mata jaring ( $\mathrm{M}$, mesh size, diukur stretched mesh, dalam $\mathrm{cm}$ ) mengikuti persamaan: $G_{m}=1,23+2,24 \quad M$. Peraturan daerah (Perda) Kabupaten Wonogiri menetapkan bahwa ukuran mata jaring minimal (paling kecil) yang boleh dipakai untuk penangkapan ikan ialah ukuran $5,1 \mathrm{~cm}$ (2 inci). Bila data pada Gambar 1 dianalisis lebih lanjut memakai kedua persamaan di atas menunjukkan bahwa hanya $7,8 \%$ ikan yang tertangkap memakai gillnet berukuran mata jaring kurang dari $5,1 \mathrm{~cm}$ (2 inci), ikan-ikan tersebut panjangnya antara 8-17 cm dan beratnya antara 20100 gram. Fenomena tersebut menunjukkan bahwa nelayan di waduk ini masih taat terhadap peraturan yang ditetapkan oleh Pemerintah Daerah setempat dalam rangka pengelolaan sumber daya ikan, yaitu tentang larangan penggunaan mata jaring kurang dari 2 inci $(5,1 \mathrm{~cm})$.

Hasil analisis panjang total ikan tawes dari tangkapan nelayan setiap bulan di Waduk Wonogiri (Lampiran 1). diperoleh nilai $L_{\infty}=47,3 \mathrm{~cm}$ dan $k=0,42$ per tahun (Gambar 3). Artinya bahwa ikan diperkirakan mampu tumbuh hingga mencapai panjang total $47,3 \mathrm{~cm}$ dengan laju pertumbuhan sebesar 0,42 per tahun. Ukuran panjang tersebut sedikit lebih panjang dibanding yang pernah diperoleh

Tabel 1. Beberapa parameter populasi ikan tawes (Barbodes gonionotus) dari beberapa perairan Table 1. Population parameters of Java barb (Barbodes gonionotus) from different study areas

\begin{tabular}{lcccccccl}
\hline $\begin{array}{c}\text { Waduk/ } \\
\text { Reservoir }\end{array}$ & $\begin{array}{c}\mathrm{L}_{\infty} \\
(\mathbf{c m})\end{array}$ & $\begin{array}{c}\mathbf{k} \\
\left(y r^{-1}\right)\end{array}$ & $\boldsymbol{\Phi}^{\prime}$ & $\begin{array}{c}\mathbf{Z} \\
\left(y r^{-1}\right)\end{array}$ & $\begin{array}{c}\mathbf{M} \\
\left(y r^{-1}\right)\end{array}$ & $\begin{array}{c}\mathbf{F} \\
\left(y r^{-1}\right)\end{array}$ & $\mathbf{E}$ & Sumber/Source \\
\hline Wonogiri & 47,3 & 0,42 & 2.973 & 1,06 & 0,89 & 0,17 & 0,16 & Studi saat ini/Present study \\
Kedungombo & 41,9 & 0,54 & 2.977 & 1,51 & 1,1 & 0,41 & 0,27 & Kartamihardja, 1995 \\
Jatiluhur & 52,6 & 0,92 & 3,406 & 2,94 & 1,5 & 1,44 & 0,49 & Kartamihardja, 1988 \\
\hline
\end{tabular}

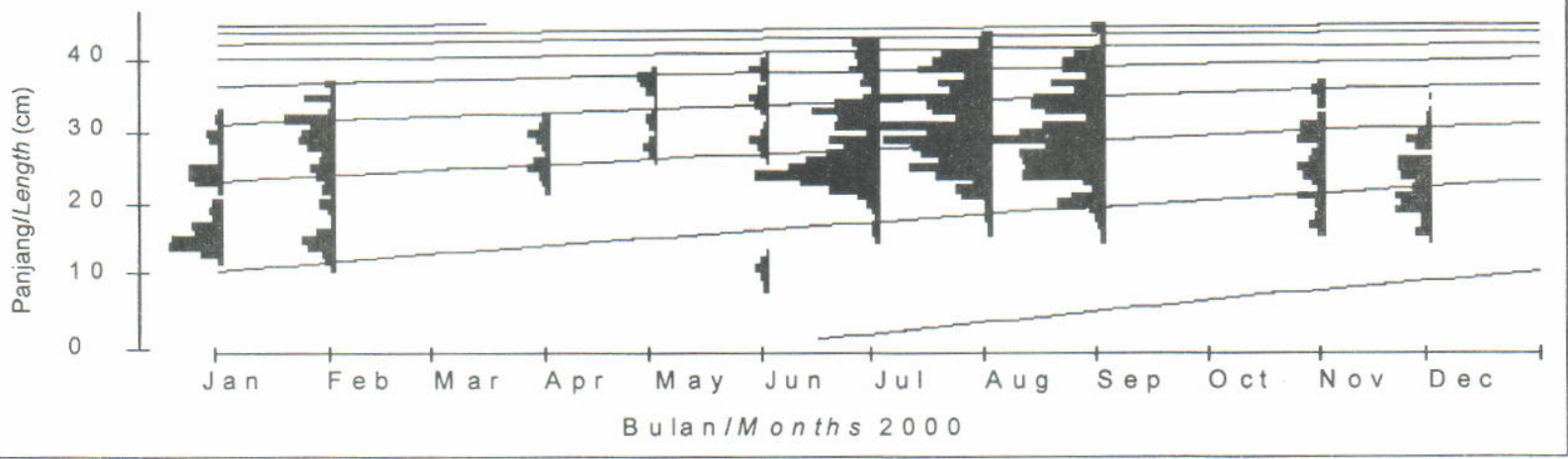

Gambar 3. Distribusi frekuensi panjang dan kurva pertumbuhan ikan tawes (Barbodes gonionotus) di Waduk Wonogiri.

Figure 3. Length frequency distribution and growth curves estimated for the Java barb (Barbodes gonionotus) in the Wonogiri reservoir. 
di Waduk Kedungombo $\left(L_{\infty}=41,9 \mathrm{~cm}\right)$ tetapi lebih pendek bila dibanding dengan yang pernah ditangkap di Waduk Jatiluhur ( $L_{\infty}=52,6 \mathrm{~cm}$ ) (Tabel 1). Dari Tabel 1 , terlihat pula bahwa laju pertumbuhan ikan tawes di Waduk Wonogiri lebih lambat dibanding kedua waduk lainnya. Berdasarkan nilai mortalitas alami, $M=0,89$ per tahun dan mortalitas penangkapan, $F=0,17$ per tahun maka diperoleh nilai laju eksploitasi, $E=0,16$ (Tabel 1).

Nilai $E$ tersebut mengindikasikan bahwa saat ini eksploitasi ikan tawes di Waduk Wonogiri masih bisa ditingkatkan hingga batas optimum tanpa mengganggu kelestariannya. Dalam hal ini diasumsikan bahwa rekruitmen di alam berlangsung secara normal atau dibantu dengan restocking dan ada upaya pengaturan alat tangkap. Upaya ini sebaiknya dilakukan dengan mengembangkan pola pengelolaan secara bersama (co-management), yaitu kerja sama antara pemerintah dan kelompok nelayan atau stakeholders lainnya. Tujuannya adalah membangkitkan partisipasi masyarakat sehingga timbul rasa memiliki dan tanggung jawab terhadap kelestarian sumber daya ikan. Untuk meningkatkan stok ikan tawes yaitu dengan menambah rekruitmennya bisa dilakukan melalui pelaksanaan program restocking (penebaran kembali). Program tersebut perlu melibatkan nelayan setempat sehingga masalah penyediaan benih dan pengelolaan perikanannya dapat berjalan dengan baik. Benih ikan tawes dapat diperoleh dari Balai Benih Ikan ( $\bar{B} B I)$ atau Unit Perbenihan Rakyat (UPR) karena jenis ikan ini sudah banyak dibudidayakan.

Berdasarkan data distribusi ukuran panjang total ikan tawes selama setahun penelitian maka diketahui ikan tawes mempunyai dua puncak rekruitmen dalam setahun (Gambar 4). Hal ini mengindikasikan bahwa ikan tawes di Waduk Wonogiri memijah beberapa kali dalam setahun. Diperkirakan pemijahan berkaitan dengan pergerakan tinggi muka air waduk, yaitu pada bulan-bulan ketika tinggi muka air waduk bergerak naik dan ketika tinggi muka air bergerak turun. Ikan tawes di waduk memijah pada bulan ketiga (Maret) dan bulan kedelapan (Agustus). Rasio antara ikan tawes jantan dan betina adalah 1:2. Di waduk Kedungombo, ikan tawes betina mulai matang kelamin pada ukuran panjang $20 \mathrm{~cm}$ dan berat $175 \mathrm{~g}$, fekunditasnya antara 25.980-86.916 butir (Kartamihardja, 1996).

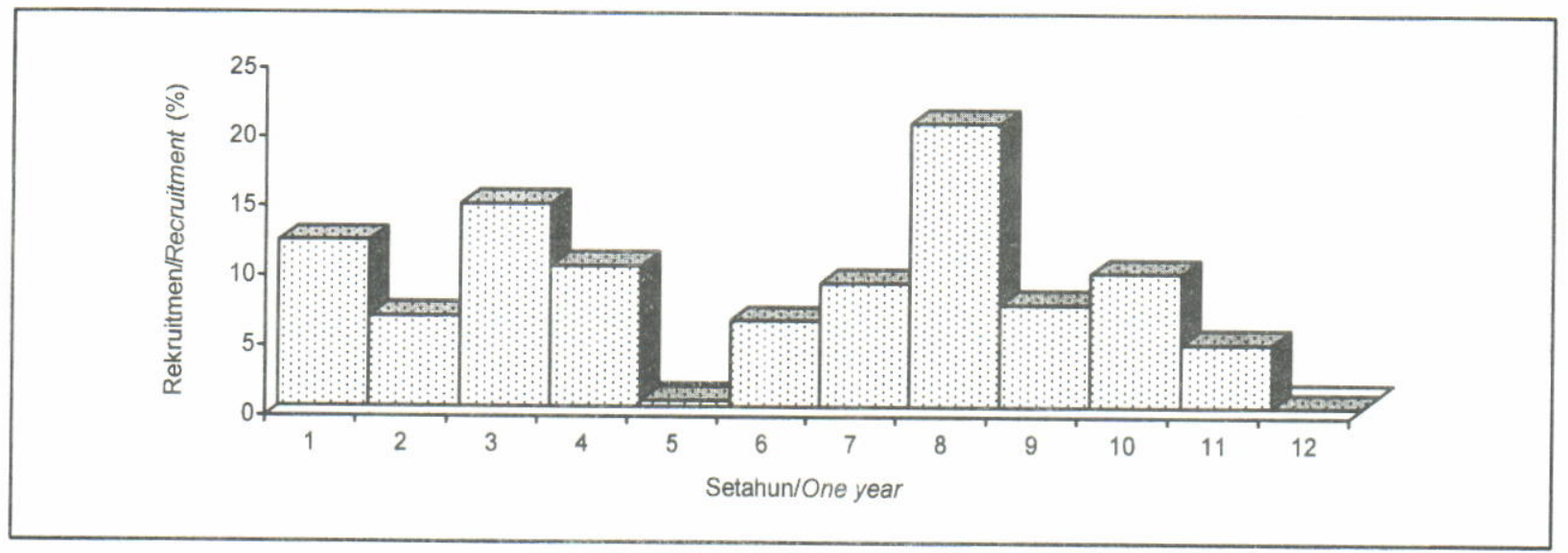

Gambar 4. Pola rekruitmen ikan tawes (Barbodes gonionotus) di Waduk Wonogiri.

Figure 4. Recruitment pattern of Java barb (Barbodes gonionotus) in the Wonogiri reservoir.

Hasil analisis isi perut 10 ekor ikan tawes dengan panjang antara $13,6-39,0 \mathrm{~cm}$ dan berat antara 40,0$1.100,0$ gram (Tabel 2) memperlihatkan bahwa makanan yang banyak dikonsumsi berturut-turut adalah berupa tumbuhan air $(80,41 \pm 1,27 \%)$, detritus $(12,17 \pm 0,95 \%)$ dan fitoplankton $(7,43 \pm 1,01 \%)$. Berdasarkan komposisi makanan yang dikonsumsi tersebut menunjukkan bahwa ikan tawes bersifat herbivora atau pemakan tumbuhan. Dari Tabel 2 juga terlihat kecenderungan bahwa dengan bertambah besarnya ukuran ikan maka makanan yang berupa tumbuhan air dikonsumsi semakin banyak. Sebaliknya persentase detritus dan fitoplankton yang dikonsumsi semakin sedikit. Menurut Haroon \& Pittman (1997), laju pengosongan perut ikan tawes adalah antara 1-5 jam pada suhu $27,5-34^{\circ} \mathrm{C}$. Menurut Purnomo (2000), tumbuhan yang dimanfaatkan adalah berupa rerumputan yang tumbuh di tepi perairan waduk maupun gulma air seperti enceng gondok (Eichhornia crassipes), kayambang (Salvinia molesta), ganggang (Hydrilla verticillata), Ceratophyllum demersum, dan kiapu (Pistia stratiotes). Fitoplankton yang dimanfaatkan kebanyakan genus dan famili Cyanophyceae, Bacillariophyceae, Chlorophyceae, dan Dinophyceae. 
Tabel 2. Komposisi makanan ikan tawes (Barbodes gonionotus) di Waduk Wonogiri

Table 2. Diet composition of Java barb (Barbodes gonionotus) in the Wonogiri reservoir

\begin{tabular}{ccccc}
\hline \multicolumn{2}{c}{ Ukuran ikan/Fish size } & \multicolumn{3}{c}{ Index of preponderance (\%) } \\
\hline $\begin{array}{c}\text { Panjang/Length } \\
\mathbf{( c m )}\end{array}$ & $\begin{array}{c}\text { Berat/Weight } \\
\mathbf{( g )}\end{array}$ & $\begin{array}{c}\text { Tumbuhan/Aquaticplants } \\
\text { Detritus }\end{array}$ & Phytoplankton \\
\hline 13,6 & 40 & 73,43 & 16,20 & 10,37 \\
16,3 & 60 & 74,75 & 15,16 & 10,09 \\
19,8 & 100 & 79,16 & 8,36 & 12,48 \\
23,0 & 160 & 80,10 & 16,08 & 3,82 \\
27,2 & 280 & 80,48 & 9,39 & 10,13 \\
31,0 & 380 & 80,74 & 11,30 & 7,96 \\
33,6 & 630 & 82,29 & 13,52 & 4,19 \\
35,0 & 680 & 82,58 & 11,19 & 6,23 \\
38,0 & 1.100 & 83,29 & 12,07 & 4,64 \\
39,0 & 800 & 87,25 & 8,39 & 4,36 \\
\hline
\end{tabular}

\section{KESIMPULAN}

1. Pertumbuhan ikan tawes (Barbodes gonionotus) di Waduk Wonogiri bersifat isometrik, artinya pertambahan panjang badan sebanding dengan pertambahan berat. Ikan tawes dapat tumbuh hingga mencapai panjang $47,3 \mathrm{~cm}$ dengan laju pertumbuhan 0,42 per tahun. Laju eksploitasi stok ikan tawes sebesar 0,16 mengindikasikan bahwa upaya penangkapan ikan ini masih bisa dikembangkan lebih lanjut.

2. Ikan tawes bersifat herbivora, makanan utamanya ialah tumbuhan air/makrofita $(73,4-87,3 \%)$ dan makanan pelengkapnya ialah detritus $(8,4-16,2 \%)$ dan fitoplankton $(7,4-12,5 \%)$.

\section{SARAN}

1. Untuk lebih meningkatkan hasil tangkapan ikan tawes di Waduk Wonogiri maka pengelola perikanan setempat perlu meningkatkan rekruitmen melalui penebaran ikan (restocking).

2. Sebaiknya pengelola perikanan setempat sejak sekarang sudah mulai melakukan monitoring dan evaluasi (monev) terhadap penggunaan alat tangkap, terutama jaring insang (gillnet).

\section{DAFTAR PUSTAKA}

Cowx, I. G. 1999. An appraisal of stocking strategies in the light of developing country constraints. Fisheries Management and Ecology (6):21-34.

Bagenal, T. B. \& F. W. Tesch. 1978. Age and growth. In: methods for assessment of fish production in freshwaters. IBP Handbook Unwin Bros. Ltd., Survey 3. 365pp.
Dulčić, J., A. Pallaoro, P. Cetinić, M. Kraljević, A. Soldo, \& I. Jardas. 2003. Age, growth, and mortality of picarel, Spicara smaris L. (Pices: Centracanthidae), from the eastern Adriatic (Croatian coast). J. Appl. Ichthyol. 19 (2003), 1014.

Effendie, M.I. 1979. Metoda biologi perikanan. Yayasan Dewi Sri. Bogor. 112p.

Gayanilo Jr F.C., P. Sparre \& D. Pauly. 1995. The FAO-ICLARM stock assessment tools (FISAT) User 's guide. FAO computerized information series: fisheries. ICLARM Contribution 1048. 126 pp.

Haroon, A. K. Y. \& K.A. Pittman. 1997. Diel feeding pattern and ration of two sizes of silver barb, Puntius gonionotus Bleeker, in nursery pond and ricefield. Aquaculture Research 28 (11), 847-858.

Kartamihardja, E. S. 1988. Analisis cohort dan pengelolaan stok ikan tawes, Puntius gonionotus di Waduk Juanda, Jawa Barat. Buletin Penelitian Perikanan Darat. Vol. 7 No. 1. Hal. 14-21.

Kartamihardja, E. S. 1995. Population dynamics of three species of Cyprinids in Kedungombo reservoir. IFR Journal 1(1): 42-57.

Kartamihardja, E. S. 1996. Structure of fish community and reproductive biology of three indigenous species of Cyprinids in Kedungombo Reservoir. IFR Journal 2(1):10-18.

Lorenzen, K., Amarasinghe, U. S., Bartley, D. M., Bell, J. D., Bilio, M., de Silva, S. S., Garaway, C. J., Hartmann, W. D., Kapetsky, J. M., Laleye, P., Moreau, J., Sugunan, V. V. \& Swar, D. B. 2001. Strategic review of enhancements and culture- 
based fisheries. In: R.P. Subasinghe, P. Bueno, M.J. Phillips, C. Hough, S.E. McGladdery \& J.R. Arthur, eds. Aquaculture in the Third Millennium. Technical Proceedings of the Conference on Aquaculture in the Third Millennium, Bangkok, Thailand, 20-25 February 2000. pp. 221-237. NACA, Bangkok and FAO, Rome.

Pauly, D. 1980. A selection of simple methods for the assessment of tropical fish stocks. FAO Fish. Circ. $729,54 \mathrm{pp}$.

Pauly, D. 1983. Length-converted catch curves: a powerful tool for fisheries research in the tropics (Part I). ICLARM Fishbyte 2, 9-13.

Pauly, D., 1984. Some simple methods for the assessment of tropical fish stocks. FAO Fish. Tech. Pap. (234): $52 \mathrm{p}$

Pauly, D. \& Munro, J. L. (1984) Once more on the comparison of growth in fish and invertebrates. ICLARM Fishbyte 2, 21.

Purnomo, K. 1997. Length-girth relationships of Barbodes gonionotus and Hampala macrolepidota in the Jatiluhur Reservoir, Indonesia. Naga, ICLARM Q. 20 (1):46-47.

Purnomo, K. 2000. Kompetisi dan pembagian sumber daya pakan komunitas ikan di Waduk Wonogiri. Jurnal Penelitian Perikanan Indonesia. Vol. 6, No. 3-4: 16-23.

Purnomo, K, E. S. Kartamihardja, \& S. Koeshendrajana. 2003. Pertumbuhan, mortalitas, dan kebiasaan makan ikan patin siam (Pangasius hypophthalmus) introduksi di Waduk Wonogiri. Jurnal Penelitian Perikanan Indonesia. Vol. 9, No. 3: $13-26$

Welcome, R. L. 1996. Stocking as a technique for enhancement of fisheries. FAO Aquaculture Newsletter (FAN), 14:8-11.

Welcomme, R. L. \& D. M. Bartley. 1998. An evaluation of present techniques for the enhancement of fisheries, p. 1-36. In: T. Petr (ed). Inland fishery enhancements. Papers presented at the FAO/DFID. Expert consultation on inland fishery enhancement. Dhaka, Bangladesh, 7-11 April 1997. FAO Fish. Tech. Pap. No. 374. Rome. 
Lampiran 1. Distribusi frekwensi panjang total ikan tawes, Barbodes gonionotus di Waduk Wonogiri Appendix 1. Length frequency distribution of Java barb, Barbodes gonionotus in Wonogiri reservoir

\begin{tabular}{|c|c|c|c|c|c|c|c|c|c|c|}
\hline \multirow{2}{*}{$\begin{array}{l}\text { Panjang/Length } \\
\text { (cm) }\end{array}$} & \multicolumn{10}{|c|}{2000} \\
\hline & Jan & Peb & Apr & Mei & Jun & Jul & Agst & Sept & Nop & Des \\
\hline 8 & & & & & 2 & & & & & \\
\hline 9 & & & & & 2 & & & & & \\
\hline 10 & & & & & 4 & & & & & \\
\hline 11 & & 2 & & & 6 & & & & & \\
\hline 12 & 1 & 4 & & & 3 & & & & & \\
\hline 13 & 8 & 5 & & & 1 & & & & & \\
\hline 14 & 21 & 11 & & & & & & & & \\
\hline 15 & 20 & 13 & & & & 1 & & 1 & & 1 \\
\hline 16 & 11 & 7 & & & & 2 & 1 & 1 & 2 & 7 \\
\hline 17 & 12 & 2 & & & & 2 & 1 & 2 & 6 & 5 \\
\hline 18 & 4 & 2 & & & & 1 & 2 & 3 & 4 & 5 \\
\hline 19 & 5 & 3 & & & & 2 & 2 & 5 & 3 & 15 \\
\hline 20 & 4 & 6 & & & & 4 & 2 & 18 & 4 & 13 \\
\hline 21 & & 2 & & & & 7 & 11 & 12 & 10 & 15 \\
\hline 22 & 1 & 5 & 1 & & & 20 & 13 & 4 & 2 & 8 \\
\hline 23 & 10 & 4 & 2 & & & 31 & 7 & 8 & 5 & 7 \\
\hline 24 & 13 & 7 & 4 & & & 50 & 22 & 32 & 8 & 13 \\
\hline 25 & 13 & 10 & 8 & & & 36 & 32 & 31 & 10 & 14 \\
\hline 26 & 2 & 6 & 6 & 2 & 1 & 29 & 21 & 32 & 6 & 14 \\
\hline 27 & 2 & 5 & 1 & 4 & 4 & 21 & 28 & 34 & 5 & \\
\hline 28 & 2 & 11 & 2 & 6 & 5 & 13 & 31 & 23 & 2 & 7 \\
\hline 29 & 5 & 14 & 5 & 4 & 8 & 20 & 42 & 50 & 10 & 10 \\
\hline 30 & 6 & 13 & 8 & 1 & 3 & 4 & 26 & 33 & 9 & 6 \\
\hline 31 & 1 & 9 & 3 & 4 & 2 & 16 & 48 & 24 & 9 & 3 \\
\hline 32 & 3 & 20 & 2 & 5 & 1 & 15 & 13 & 7 & 2 & 3 \\
\hline 33 & 2 & 3 & & 3 & 3 & 27 & 23 & 22 & & 1 \\
\hline 34 & & 2 & & 1 & 6 & 17 & 25 & 29 & 2 & \\
\hline 35 & & 12 & & 1 & 8 & 5 & 43 & 28 & 2 & 1 \\
\hline 36 & & 1 & & 5 & 5 & 2 & 15 & 11 & 5 & \\
\hline 37 & & 4 & & 7 & 1 & 6 & 21 & 20 & 2 & \\
\hline 38 & & & & 8 & 3 & 5 & 10 & 6 & & \\
\hline 39 & & & & 3 & 8 & 11 & 29 & 15 & & \\
\hline 40 & & & & & 4 & 8 & 23 & 15 & & \\
\hline 41 & & & & & 1 & 9 & 20 & 11 & & \\
\hline 42 & & & & & & 8 & 4 & 3 & & \\
\hline 43 & & & & & & 10 & 4 & 1 & & \\
\hline 44 & & & & & & & 3 & 1 & & \\
\hline 45 & & & & & & & & 4 & & \\
\hline
\end{tabular}

